\title{
Analisis SWOT Terhadap Pelaksanaan Bauran Pemasaran (Marketing Mix) Pada Lembaga Pendidikan Prima Mandiri Utama Palangka Raya
}

\author{
Fendy Hariatama \\ Program Magister Pendidikan Ekonomi, Pascasarjana Universitas Palangka Raya \\ *Correspondence author: fhariatama@gmail.com ; Tel.: +6282231071994
}

\begin{abstract}
This research focuses on the marketing strategy, which is one of the principle activities done by companies in their effort to secure and enhance the longevity of their business. It also creates and enhances the demands made by consumers. Therefore, increasing sell revenue and making more profits from it. In their effort to get maximum profits, the companies must be able to run the center point of marketing mix. The best way to do it is by applying the SWOT analysis - which stands for strength, weakness, opportunities, and threats - to each of the variable in the marketing mix. The research uses descriptive qualitative method. This method is applied to an educational institution called "prima mandiri utama". There are three steps in acquiring the data, namely: observation, interview, and documentation. Next, the activities within the institution is discussed and analyzed. The validity of the data is strengthened by the further exploration of other sources which are taken from numerous important individuals, namely: the president director, HR manager, the academic manager marketing coordinators and staffs, also the students and parents. The research shows that the marketing mix in "Prima Mandiri Utama" is still unbalance; this can be seen from the SWOT analysis of the seven variables which do not get an even attention. Some variables get neglected whereas some other is being overly done. Nonetheless, the marketing mix strategy in "Prima Mandiri Utama" has been very well done; this can be seen from mobile implementation of it, the institution does not imitate the rival companies, they are also managed to comprehend the situation around the institution although the future planning is not significant yet.
\end{abstract}

Keywords: Educational Institutions, Marketing Mix, SWOT Analysis.

Abstrak: Penelitian ini mempelajari tentang pemasaran yang merupakan salah satu kegiatan pokok yang dilakukan oleh perusahaan dalam upaya menjaga dan meningatkan kelangsungan hidup usahanya, serta untuk menciptakan dan meningkatkan permintaan sehingga terjadi peningkatan volume penjualan dan mendapatkan keuntungan. Dalam upaya mendapatkan laba maksimal, perusahaan harus bisa menjalankan dengan baik titik sentral dari terjadinya kegiatan pemasaran yaitu bauran pemasaran (marketing mix), pelaksanaan bauran pemasaran (marketing mix) yang baik adalah dengan melakukan analisis SWOT yaitu kekuatan (strength), kelemahan (weakness), kesempatan/ peluang (opportunities), dan ancaman (threats), pada masing-masing variabel dalam bauran pemasaran (marketing $\mathrm{mix}$ ). Metode penelitian yang digunakan untuk meneliti lembaga pendidikan prima mandiri utama Palangka Raya Jl. G.Obos nomor 68 ruko GHIJ Kota Palangka Raya menggunakan pendekatan penelitian deskriptif kualitatif, dengan cara mengumpulkan data melalui tiga tahapan yaitu, observasi, wawancara mendalam, dan dokumentasi. Barulah kemudian data diklasifikasikan sekaligus dianalisis dengan aktivitas yang meliputi reduksi data, penyajian data, dan penarikan kesimpulan atau verifikasi data. Kebenaran data juga diperkuat dengan mengeksplorasi beberapa sumber sehingga meningkatkan kepercayaan penelitian. Adapun sasaran atau obyek penelitian ditujukan kepada lembaga pendidikan prima mandiri utama dengan informan yaitu, Presiden Director, HRD Manager, Academic Manager, Marketing Coordinator dan Staff, orang tua/wali siswa, dan siswa(i) lembaga pendidikan prima mandiri utama Palangka Raya. Hasil penelitian menunjukan bahwa pelaksanaan bauran pemasaran (marketing mix) pada lembaga pendidikan prima mandiri utama masih belum seimbang, hal ini dapat dilihat berdasarkan analisis SWOT yang dilakukan terhadap ketujuh variabel bauran pemasaran (marketing mix) yang mana masih terdapat variabel yang belum mendapat perhatian yang cukup baik dari manajemen lembaga pendidikan prima mandiri utama sementara ada beberapa variabel yang pelaksanaannya dilakukan secara besar-besaran. Meskipun demikian, bauran pemasaran (marketing mix) pada lembaga pendidikan prima mandiri utama sudah dijalankan dengan baik, hal ini dapat dilihat dari pelaksanaan bauran pemasaran (marketing mix) yang tidak statis, tidak meniru bimbingan belajar pesaing, serta disesuaikan 
dengan situasi dan kondisi perusahaan, meskipun dalam perencanaan tujuan jangka panjangnya, terlihat belum signifikan.

Kata kunci: Lembaga Pendidikan, Bauran Pemasaran (Marketing Mix), Analisis SWOT.

\section{PENDAHULUAN}

Penyelenggaraan pendidikan menjadi tanggung jawab bersama antar pemerintah dan masyarakat, begitulah bunyi yang tertuang dalam Undang-undang Dasar 1945 pasal 31 dan Undangundang No.2 tahun 1989 tentang sistem pendidikan nasional di Indonesia. Hal tersebut menunjukan bahwa penyelenggaraan pendidikan di Indonesia tidak hanya dilakukan di sekolah formal saja melainkan dapat diselenggarakan oleh lembaga pendidikan diluar sekolah seperti lembaga pendidikan non formalm atau yang biasanya lebih dikenal Bimbingan Belajar (Bimbel). Oleh karena itu, bimbingan belajar mempunyai peranan yang kuat sebagai wujud partisipasi masyarakat dalam rangka mencerdaskan kehidupan bangsa. Dewasa ini perkembangan bimbingan belajar di Indonesia sangat pesat, baik daerah pedesaan sampai dengan perkotaan mudah sekali bagi para orangtua untuk mencarikan bimbingan belajar kepada putra-putrinya. Di daerah pedesaan contohnya banyak terdapat les privat yang mana bimbingan belajar ini didominasi oleh para guru yang pada dasarnya sudah tidak asing lagi dengan dunia pendidikan karena profesinya yang merupakan tenaga pengajar atau pendidik. Begitupun halnya dengan daerah perkotaan yang juga terdapat guru-guru yang memberikan jasa les privat karena hal tersebut dijadikan pekerjaan sampingan yang dikerjakan setelah pulang mengajar, sore maupun pada malam hari. Namun khusus daerah perkotaan perkembangan bimbingan belajar jauh lebih pesat jika dibanding daerah pedesaan, bimbingan belajar daerah perkotaan tidak lagi bertumpuan hanya pada guru-guru yang membuka layanan les privat kerumah-rumah siswa atau mendatangkan siswa untuk mengikuti les privat dirumah guru tersebut, melainkan hal ini dilihat sebagai sebuah peluang oleh para pengusaha maupun pelaku dalam dunia pendidikan untuk menjadikan bimbingan belajar sebagai ladang bisnis untuk menghasilkan income yang besar dan menjanjikan. Oleh karena itu, di daerah perkotaan banyak terdapat kantor-kantor bimbingan belajar atau juga dikenal lembaga pendidikan non formal yang berdiri dengan menawarkan layanan jasa les kepada masyarakat. Mengikuti bimbingan belajar sangat baik bagi anak-anak yang sedang menempuh pendidikan formal, baik jenjang Sekolah Dasar (SD) sederajat, Sekolah Menengah Pertama (SMP) sederajat, dan Sekolah Mengengah Atas (SMA) sederajat, karena dengan mengikuti bimbingan belajar diharapkan dapat meningkatkan prestasi akademik anak di lingkungan sekolah serta meningkatkan rasa percaya diri anak. Ini yang menyebabkan banyak orangtua memberikan pendidikan tambahan kepada putra-putrinya dengan mengikut sertakan putra-putrinya pada kegiatan les yang diselenggarakan oleh lembaga pendidikan non formal/ bimbingan belajar yang ada saat ini.

Penomena perubahan pola pendidikan yang begitu cepat dewasa ini, serta arus globalisasi yang merembet di segala bidang termasuk bidang pendidikan, memunculkan persaingan yang sangat ketat pada bidang bisnis pelayanan jasa pendidikan. Lembaga pendidikan non formal seperti bimbingan belajar harus selalu siap mengadapi strategi-strategi yang dikeluarkan oleh pesaing bimbingan belajar sejenis, sekolah-sekolah yang menyelenggarakan bimbingan belajar, serta dengan guru-guru yang menyelenggarakan les privat. Sehingga dalam menghadapi persaingan yang sangat ketat dewasa ini, manajemen pemasaran sebuah bimbingan belajar merupakan prioritas yang harus di optimalkan dalam memberikan pelayanan kepada masyarakat serta menyebarluaskan informasi kepada masyarakat terkait keberadaan bimbingan belajar yang bersangkutan. Selanjutnya, sangat penting untuk memperhatikan masalah kebijakan pemasaran dan pemasaran produk jasa (the service product) guna memenuhi kebutuhan konsumen, mengingat pemasaran sendiri merupakan langkah awal proses sosial masyarakat dalam menciptakan dan menawarkan produk/jasa yang benilai serta bermanfaat satu sama lain. Salah satu indikator yang digunakan untuk melihat efektifitas proses pemasaran yaitu dilihat dari kebijaksanaan pelaksanaan bauran pemasaran (marketing mix) yang dijalankan oleh sebuah lembaga pendidikan/ bimbingan belajar. Permasalahan yang terjadi dewasa ini, kurang efektifnya pelaksanaan 
bauran pemasaran (marketing mix) yang dijalankan oleh bimbingan belajar maupun sektor usaha lainnya, sehingga dalam proses pelaksanaan yang meliputi tujuh komponen penting yaitu produk (product), harga (price), tempat/lokasi layanan (place/service location), promosi (promotion), orang/partisipan (people), sarana fisik (physical evidence), dan proses (process), perlu dioptimalkan pelaksanaannya secara profesional dan totalitas. Kurang efektinya pelaksanaan bauran pemasaran (marketing mix) ini, merupakan hasil observasi awal/ pengamatan partisifatif yang penulis lakukan sebelum turun lapangan secara mendalam dalam rangka melakukan proses penelitian, mengumpulkan data serta melakukan analisis atas data tersebut. Kekurang efektifan pelaksanaan strategi bauran pemasaran (marketing mix) dilihat dari masing-masing poin, seperti: produk (product) yang di tawarkan masih belum lengkap hingga ke pelatihan-pelatihan secara khusus. Harga (price) yang di tawarkan sama rata, baik jenjang sekolah dasar (SD) sederajat, sekolah menengah pertama (SMP) sederajat, maupun jenjang sekolah menengah atas (SMA) sederajat, masih di harga yang sama. Tempat/lokasi layanan (place/service location) hanya terfokus pada satu lokasi sehingga sulit di jangkau oleh siswa(i) yang berada di lokasi/ kecamatan yang berbada. Begitu juga dengan promosi (promotion), orang/partisipan (people), sarana fisik (physical evidence), dan proses (process), yang masih terlihat belum maksimal. Sehingga untuk mendapatkan sebuah formulasi strategi yang baik ke-tujuh komponen yang terdapat dalam sistem bauran pemasaran (marketing mix) perlu dilakukan identifikasi secara sistematis, komperatif dan strategis untuk merumuskan strategi yang baik. Analisis semaca ini dikenal dengan sebutan analisis SWOT (Stenght, Weaknesses, Opportunities, and Threats) yaitu analisis keluatan, kelemahan, kesempatan/peluang, dan ancaman. Kota Palangka Raya terdapat cukup banyak lembaga pendidikan non formal/ bimbingan belajar, dimana lembaga ini dari tahun ke tahun jumlahnya semakin meningkat, hal ini disebabkan karena permintaan para orangtua untuk meningkatkan kemampuan kualitas akademik putra-putrinya yang semakin besar, untuk jelasnya dapat dilihat dalam tabel berikut ini :

Tabel 1. Lembaga Pendidikan di Palangka Raya

\begin{tabular}{|c|l|l|}
\hline No. & \multicolumn{1}{|c|}{ Nama } & \multicolumn{1}{c|}{ Alamat } \\
\hline 1 & Prima Mandiri Utama & Jl. G. Obos No 68 Ruko GHIJ, Palangka Raya \\
\hline 2 & Sony Sugema College & Jl. Tjilik Riwut No 04, Palangka Raya \\
\hline 3 & Primagama & Jl. Kahayan No 4, Palangka Raya \\
\hline 4 & Eduprana & $\begin{array}{l}\text { Jl. D.I Panjaitan No 1, Gedung Batang } \\
\text { Garing Lantai 2 kav 202 }\end{array}$ \\
\hline 5 & Mario English Course & Jl. Kakatua No 38, Palangka Raya \\
\hline 6 & Bina Prestasi & Jl. Garuda \\
\hline 7 & Tutor Spektrum & $\begin{array}{l}\text { Jl. RTA Millono KM 2,5 Komp. Masjid Fathul } \\
\text { Iman No 48 }\end{array}$ \\
\hline
\end{tabular}

Sumber: Galeri Disdik Kota Palangka Raya Tahun 2016

Salah satu lembaga pendidikan non formal/ bimbingan belajar yang ada di Kota Palangka Raya adalah Lembaga Pendidikan PRIMA MANDIRI UTAMA yang beralamat di JI.G.Obos No.68 Ruko G-H-I-J Palangka Raya. Lembaga pendidikan Prima Mandiri Utama saat ini memiliki daya tarik tersendiri ditengah ketetnya persaingan antar bimbingan belajar yang semakin ketat. Seperti, disediakannya fasilitas mobil antar jemput siswa sehinnga para orangtua/ wali siswa yang memiliki kesibukan tidak merasa kebingungan untuk transfortasi putra-putrinya saat mengikuti bimbingan belajar karena adanya fasilitas antar jemput tersebut. Bukan hanya persaingan yang semakin ketat yang menjadi tantangan dari lembaga pendidikan Prima Mandiri Utama, melainkan bagaimana strategi pemasaran yang dilakukan dalam rangka mendapatkan kepercayaan dari masyarakat, dan merebut konsumen yang ada dari pesaing, serta mendapatkan siswa dengan jumlah yang semaksimal mungkin, itu yang menjadi tantangan utama yang harus dihadapi lembaga pendidikan Prima Mandiri Utama. Kemudian dalam melaksanaan bauran pemasaran (marketing mix) lembaga pendidikan Prima Mandiri Utama menjadi 
menarik untuk diketaui, mengingat lembaga pendidikan Prima Mandiri Utama memberanikan diri untuk berdiri dan memulai dari awal menjadi bagian dari bimbingan belajar yang ada di Kota Palangka Raya ditengah-tengah sudah banyaknya lembaga pendidikan lain yang memang sudah berdiri lebih awal sebelum hadirnya lembaga pendidikan/ bimbingan belajar Prima Mandiri Utama. Selain itu, kondisi saat ini dalam tubuh organisasi lembaga sendiri memiliki beberapa permasalahan yang dihadai, seperti : kurangnya sumber daya manusia yang berkualitas baik, seringnya terjadi konflik internal antar divisi maupun individu karyawan sendiri, serta semakin tuanya usia fasilitas yang dimiliki lembaga pendidikan Prima Mandiri Utama sehingga beberapa fasilitas fungsinya ada yang sudah tidak berjalan sebagaimana mestinya. Meskipun demikian, tidak menyurutkan semangat dan tanggungjawab dari lembaga pendidikan Prima Mandiri Utama untuk mengabdi dan mencerdaskan kehidupan bangsa dan menjadi market leader dalam persaingan bimbingan belajar di Kota Palangka Raya. Sehingga, dalam mewujudkan harapan memiliki siswa yang banyak dan berkualitas serta menjadi market leader tersebut tentu tidak mudah. Bimbingan-bimbingan belajar pesaing tentunya memiliki strategi tersendiri untuk mempertahankan bimbingan belajar nya dan memiliki tekad yang sama untuk menjadi yang terdepan dalam memberikan pelayanan dan memuaskan konsumen. Sehingga, untuk mencapai tujuan tersebut pelaksanaan bauran pemasaran (marketing mix) yang dilandasi dengan analisis SWOT yang sistematis, komparatif dan strategis akan sangat membantu dalam rangka melaksanakan strategi bauran pemasaran (marketing mix) yang tepat guna pencapaian target yang telah ditetapkan oleh perusahaan. Demikian pula sebaliknya, pelaksanaan bauran pemasaran (marketing mix) yang belum optimal, serta tidak diiringi dengan analisis yang mendalam terkait keluatan, kelemahan, peluang/ kesempatan, dan ancaman yang ada maka akan mempengaruhi sektor pemasaran itu sendiri. Berdasarkan uraian di atas maka penulis merasa tertarik untuk melaksanakan sebuah penelitian mendalam terhadap pelaksanaan bauran pemasaran (marketing mix) pada Lembaga Pendidikan PRIMA MANDIRI UTAMA tersebut, dengan mengangkat sebuat judul penelitian "ANALISIS SWOT TERHADAP PELASKANAAN BAURAN PEMASARAN (MARKETING MIX) PADA LEMBAGA PENDIDIKAN PRIMA MANDIRI UTAMA PALANGKA RAYA".

\section{METODE}

Pada penelitian kali ini, peneliti menggunakan pendekatan penelitian deskriptif kualitatif, yang mana ahli data yang dikumpulkan berupa kata-kata, gambar, dan bukan angka-angka. Selain itu semua yang dikumpulkan berkemungkinan menjadi kunci terhadap apa yang sudah diteliti. Penelitian kulitatif adalah metode penelitian yang berlandaskan pada filsafat postpositivisme, digunakan untuk meneliti pada kondisi objek yang alamiah, (sebagai lawannya eksperimen) dimana peneliti adalah sebagai instrument kunci, pengambilan sampel sumber data dilakukan secara purposive dan snowbaal, teknik pengumpulan dengan triangulasi (gabungan), analisis data bersifat induktif/kualitatif, dan hasil penelitian kualitatif lebih menekankan makna dari pada generalisasi. Penelitian kualitatif adalah tampilan yang berupa kata-kata lisan atau tertulis yang dicermati oleh peneliti, dan benda-benda yang diamati sampai detailnya agar dapat ditangkap makna yang tersirat dalam dokumen atau bendanya

Tabel 2. Informan Penelitian

\begin{tabular}{|c|l|r|c|}
\hline No. & \multicolumn{1}{|c|}{ Jenis Populasi } & Jumlah & Keterangan \\
\hline 1 & Direktur Utama & 1 orang & Informan \\
\hline 2 & HRD & 1 orang & Informan \\
\hline 3 & Co Marketing & 1 orang & Informan \\
\hline 4 & Staff Marketing & 3 orang & Informan \\
\hline 5 & Devisi Akademik & 17 orang & Informan \\
\hline 6 & Orang tua siswa (SD,SMP,SMA) & 17 orang & Informan \\
\hline 7 & Siswa (SD,SMP,SMA) & & Informan \\
\hline
\end{tabular}


Sumber Data: Informan penelitian Pelaksanaan marketing mix pada lembaga pendidikan Prima Mandiri Utama Palangka Raya.

\section{HASIL DAN PEMBAHASAN}

Sejarah Terbentuknya Lembaga Pendidikan Prima Mandiri Utama Palangka Raya bermula dari sebuah keinginan mulia yang ada dalam benak Ibu Emi, untuk membagikan ilmu yang dimilikinya (kemampuan berbahasa inggris) kepada anak-anak yang ada disekitar tempat tinggalnya. Sebuah citacita mulia, yang ingin ikut serta mencerdaskan kehidupan bangsa melalui generasi muda yang memiliki semangat tinngi dalam belajar dan menuntut ilmu. Juli tahun 2006, menjadi awal mula sejarah terbentuknya lembaga pendidikan prima mandiri utama yang tidak akan terlupakan hingga saat ini. Setiap perusahaan pada umumnya mempunyai struktur organisasi, demikian juga dengan lembaga pendidikan Prima Mandiri Utama. Penyusunan struktur organisasi merupakan langkah awal dalam memulai pelaksanaan kegiatan organisasi.

\section{Deskripsi Hasil Penelitian}

Proses bimbingan belajar dan tahapan proses bimbingan belajar, seperti terlihat pada gambar berikut ini:

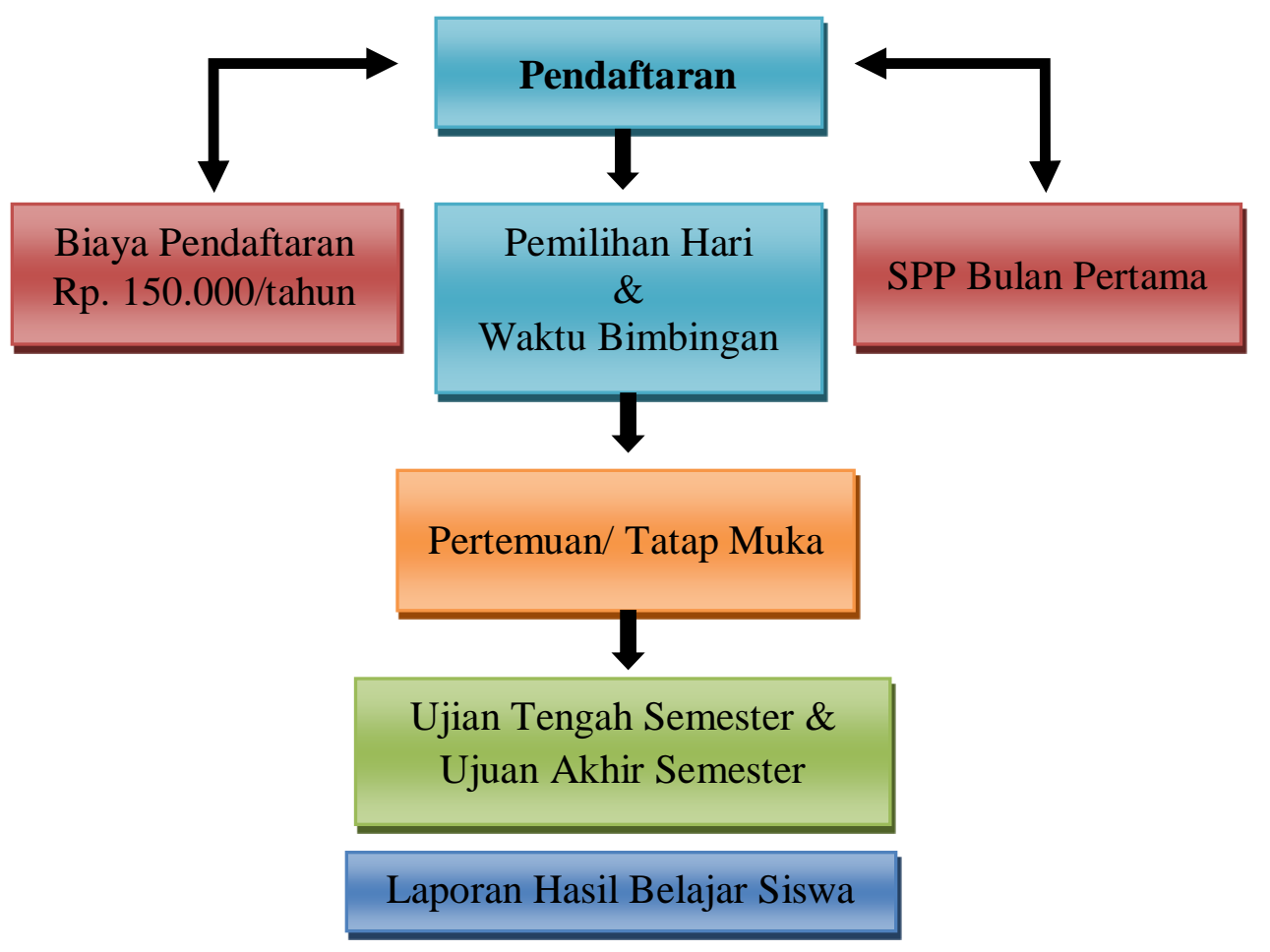

Gambar 1. Tahapan Proses Bimbingan Belajar Lembaga Pendidikan Prima Mandiri Utama Palangka Raya (Sumber Data: Lembaga Pendidikan Prima Mandiri Utama 2016-2017)

Hasil belajar yang menunjukan selama menjalankan program bimbingan belajar/ les lembaga pendidikan prima mandiri utama telah menghasilkan siswa(i) yang berprestasi baik sekala lokal seperti: juara kelas, nilai ujian nasional terbaik, nilai ulangan tertinggi di sekloah, menang lomba antar sekolah, bahkan sampai sekala nasional seperti: diterima di perguruan tinggi Universitas Indonesia (UI), serta juara olimpiade matematika. Pemasaran jasa bimbingan belajar/ les pada lembaga pendidikan prima mandiri utama dilakukan dengan berbagai cara dan program, baik bertatap muka langsung dengan calon konsumen maupun melewati media seperti internet, brosur, spanduk, koran, dan media cetak lainnya. Dalam proses pemasaran lembaga pendidikan prima mandiri utama memiliki divisi sendiri yaitu 
Divisi Marketing dengan satu orang koordinator dan empat orang staff. Seperti pada gambar berikut ini:

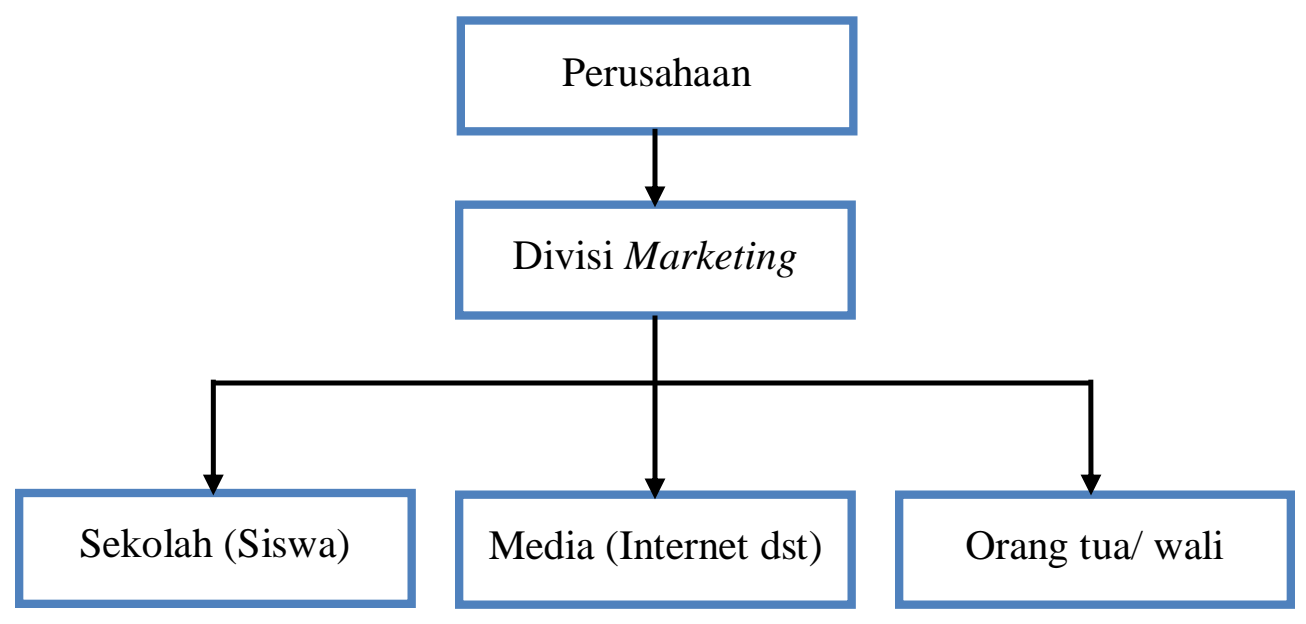

Gambar 2. Pemasaran Bimbingan Belajar Lembaga Pendidikan Prima Mandiri Utama Palangka Raya (Sumber: Lembaga Pendidikan Prima Mandiri Utama 2016-2017)

\section{Pelaksanaan Bauran Pemasaran (Merketing Mix) Pada Lembaga Pendidikan Prima Mandiri Utama Palangka Raya}

Berdasarkan keseluruhan hasil wawancara di atas dapat disimpulan bahwa variabel ketujuh yang terkandung dalam bauran pemasaran (marketing $\mathrm{mix}$ ) yaitu preses, lembaga pendidikan prima mandiri utama menjalankan proses dengan prosedur yang terjadwal serta memiliki mekanisme dan aktifitasaktifitas didalamnya. Pelaksanaan bauran pemasaran (marketing mix) lembaga pendidikan prima mandiri utama dalam rangka memuaskan keinginan dan kebutuhan konsumen melalui proses pertukaran untuk mencapai tujuan pemasaran dan menciptakan permintaan yang efektif dalam variabel ketujuhnya yaitu proses (process), lembaga pendidikan prima mandiri utama memfokuskan pada SOP yang telah ditentukan oleh lembaga pendidikan prima mandiri utama mulai dari hari dan jam kerja, pakayan kerja, proses bimbingan belajar, hingga aktifitas-aktifitas yang harus dilakukan.

\section{Analisis SWOT Terhadap Pelaksanaan Bauran Pemasaran (Marketing Mix) Pada Lembaga Pendidikan Prima Mandiri Utama Palangka Raya}

\section{Analisis Matriks Internal Factor Evaluation (IFE)}

Matriks Internal Factor Evaluation (IFE) digunakan untuk mengetahui seberapa besar pengaruh dari faktor-faktor internal yaitu kekuatan dan kelemahan lembaga pendidikan prima mandiri utama palangka raya. Untuk mengetahui kekuatan dan kelemahan lembaga pendidikan prima mandiri utama, seperti terlihat pada tabel berikut ini:

Tabel 3. Kekuatan dan Kelemahan Lembaga Pendidikan Prima Mandiri Utama Palangka Raya

\begin{tabular}{|l|l|l|c|}
\hline No & \multicolumn{2}{|c|}{ Faktor Internal } & \multicolumn{2}{|c|}{ Kekuatan } & \multicolumn{1}{c|}{ Kelemahan } \\
\hline 1. & $\begin{array}{l}\text { Produk Jasa (The } \\
\text { Service Product) }\end{array}$ & $\begin{array}{l}\text { Matarataran } \\
\text { matematika, IPA, bahasa } \\
\text { inggris yang masuk dalam }\end{array}$ & $\begin{array}{l}\text { Mata pelajaran masih belum } \\
\text { lengkap, seperti IPA biologi, } \\
\text { IPS, TIK, dan mata pelajaran } \\
\text { bahasa indonesia yang juga }\end{array}$ \\
\hline
\end{tabular}




\begin{tabular}{|c|c|c|c|}
\hline & & $\begin{array}{l}\text { ujian (ujian nasional dan } \\
\text { sekolah), } \\
\text { - Tambahan mata pelajaran } \\
\text { calistung (baca, tulis, } \\
\text { hitung) untuk siswa(i) kelas } \\
1 \text { dan } 2 \text { SD/MI, } \\
\text { - Tambahan mata pelajaran } \\
\text { kimia dan fisika untuk IPA } \\
\text { jenjang SMA/MA. }\end{array}$ & $\begin{array}{l}\text { masuk dalam ujian nasional } \\
\text { dan ujian sekolah. }\end{array}$ \\
\hline 2. & Harga (Price) & 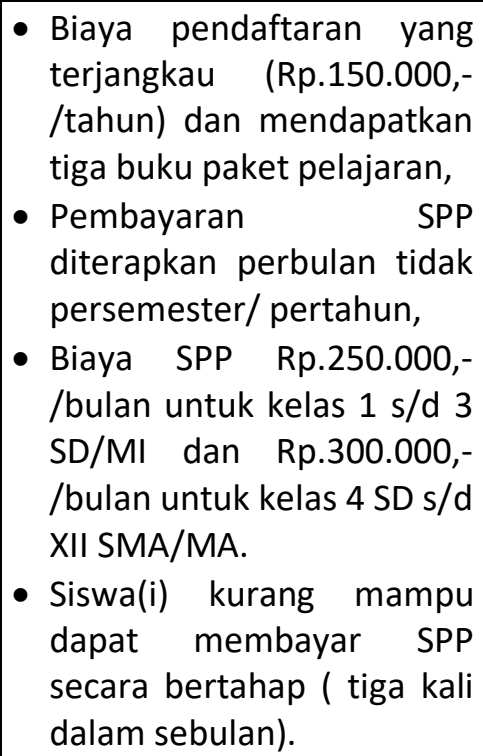 & $\begin{array}{l}\text { - Sistem pembukuan yang } \\
\text { terlalu merepotkan admin } \\
\text { head dan receptionist. }\end{array}$ \\
\hline 3. & $\begin{array}{l}\text { Tempat/Lokasi } \\
\text { Pelayanan } \\
\text { (Place/Service } \\
\text { Location) }\end{array}$ & $\begin{array}{l}\text { - Strategis dan berada di } \\
\text { areal dalam kota, } \\
\text { - Setiap devisi memiliki } \\
\text { ruangan sendiri untuk } \\
\text { melakukan pelayanan } \\
\text { sesuai } \\
\text { konsumen, } \\
\text { - Direktur memiliki ruang } \\
\text { tamu untuk menerima } \\
\text { tamu-tamu penting. }\end{array}$ & $\begin{array}{l}\text { - Siswa(i) yang rumahnya jauh } \\
\text { merasa terbebani dengan } \\
\text { jarak tersebut. }\end{array}$ \\
\hline 4. & $\begin{array}{l}\text { Promosi } \\
\text { (Promotion) }\end{array}$ & $\begin{array}{l}\text { - } \text { Memiliki strategi baik } \\
\text { internal maupun eksternal, } \\
\text { - } \text { Promosi dilakukan dengan } \\
\text { memberikan target } \\
\text { perorangan maupun terget } \\
\text { kelompok kepada divisi } \\
\text { marketing, } \\
\text { - Promosi dilakukan dengan } \\
\text { memanfaatkan } \\
\text { media (sosmed), } \\
\text { - Promosi dilakukan dengan } \\
\text { memanfaatkan webside, } \\
\text { - Promosi dilakukan dengan } \\
\text { menyebarkan informasi }\end{array}$ & $\begin{array}{l}\text { - Promosi hanya dilakukan di } \\
\text { lingkungan kota Palangka } \\
\text { Raya saja, } \\
\text { - Pemanfaatan media televisi } \\
\text { belum dilakukan, } \\
\text { - Pemanfaatan media internet } \\
\text { yang belum optimal. }\end{array}$ \\
\hline
\end{tabular}




\begin{tabular}{|c|c|c|c|}
\hline & & $\begin{array}{l}\text { melalui brosur, pamplet, } \\
\text { spanduk, dan koran, } \\
\text { - Promosi dilakukan dengan } \\
\text { mengajak siswa(i) yang } \\
\text { sudah les untuk mengajak } \\
\text { temannya dengan } \\
\text { memberikan bonus bagi } \\
\text { yang berhasil, } \\
\text { - Promosi dilakukan dengan } \\
\text { mengajak orangtua/ wali } \\
\text { siswa untuk mengajak } \\
\text { anak/keluarga dari rekan } \\
\text { mereka untuk les dan } \\
\text { diberikan bonus bagi yang } \\
\text { berhasil, } \\
\text { Promosi dilakukan dengan } \\
\text { bekerjasama dengan pihak } \\
\text { sekolah agar dapat masuk } \\
\text { ke kelas-kelas untuk } \\
\text { melakukan promosi, } \\
\text { Promosi dilakukan dengan } \\
\text { berdiskusi secara langsung } \\
\text { dengan calon konsumen } \\
\text { (orang tua/ wali siswa, dan } \\
\text { siswa). }\end{array}$ & \\
\hline 5. & $\begin{array}{l}\text { Orang/partisipan } \\
\text { (People) }\end{array}$ & $\begin{array}{l}\text { - Proses recruitment yang } \\
\text { ketat, } \\
\text { - Tenaga pengajar } \\
\text { berpendidikan minimal } \\
\text { lulusan sarjana, hingga } \\
\text { lulusan program magister, } \\
\text { - Tenaga pengajar mengajar } \\
\text { sesuai disiplin ilmu masing- } \\
\text { masing, } \\
\text { - Setiap divisi memiliki } \\
\text { kepala divisi/manager, } \\
\text { - People berpenampilan rapi } \\
\text { dan formal. }\end{array}$ & $\begin{array}{lr}\text { - } \text { Keterbatasan } & \text { tenaga } \\
\text { pengajar, sehingga tidak bisa } & \text { keinginan } \\
\text { memenui } & \text { hendak } \\
\text { konsumen jika } & \text { proses } \\
\text { mengadakan } & \text { diluar } \\
\text { pembelajaran } & \text { pelayanan } \\
\text { tempat/lokasi } & \text { lembaga. }\end{array}$ \\
\hline 6. & $\begin{array}{l}\text { Fasilitas Penunjang } \\
\text { (Physical Evidence) }\end{array}$ & $\begin{array}{l}\text { - Halaman parkir yang luas, } \\
\text { - Ruang kelas full AC, } \\
\text { - Ruang kelas terpasang } \\
\text { kamera CCTV, } \\
\text { - Free WiFi } \\
\text { - Minuman gratis } \\
\text { - Kursi moderen (kursi lipat + } \\
\text { - } \text { meja) } \\
\text { - Kantar jemput siswa } \\
\text { Kantin sehat }\end{array}$ & $\begin{array}{l}\text { - Fasilitas tidak dirawat } \\
\text { dengan baik, } \\
\text { - Beberapa ruangan AC sudah } \\
\text { tidak dingin lagi, } \\
\text { - WiFi dengan kuota rendah } \\
\text { sehingga saat digunakan } \\
\text { bersamaan dalam jumlah } \\
\text { pengguna yang banyak akan } \\
\text { sangat lambat, }\end{array}$ \\
\hline
\end{tabular}




\begin{tabular}{|l|l|l|l|}
\hline & $\begin{array}{l}\text { - Free konsultasi mata } \\
\text { pelajaran, } \\
\text { - Free konsultasi PR } \\
\text { (pekerjaan rumah). }\end{array}$ & $\begin{array}{l}\text { Antar jemput siswa kadang } \\
\text { terlambat dari jadwal yang } \\
\text { telah disepakati, } \\
\text { Tidak memiliki ruang baca/ } \\
\text { mini perpustakaan. }\end{array}$ \\
\hline 7. & Proses (Process) & $\begin{array}{l}\text { - Miliki standar operasional } \\
\text { kerja, } \\
\text { - Pembagian jadwal, hari, } \\
\text { dan jam kerja masing- } \\
\text { masing divisi jelas, } \\
\text { Berpedoman pada aturan ada jam layanan pada } \\
\text { dan tatib organisasi. }\end{array}$ & $\begin{array}{l}\text { Tidaktu pagi hari, baik } \\
\text { administrasi, konsultasi } \\
\text { produk, maupun program- } \\
\text { program lainnya. }\end{array}$ \\
\hline
\end{tabular}

\section{Analisis Matriks Eksternal Factor Evaluation (EFE)}

Matriks Eksternal Factor Evaluation (EFE) digunakan untuk mengetahui seberapa besar pengaruh dari faktor-faktor eksternal yaitu peluang dan ancaman lembaga pendidikan prima mandiri utama palangka raya. Untuk mengetahui peluang dan ancaman lembaga pendidikan prima mandiri utama, seperti terlihat pada tabel berikut ini:

Tabel 4. Peluang dan Ancaman Lembaga Pendidikan Prima Mandiri Utama Palangka Raya

\begin{tabular}{|c|c|c|c|}
\hline No & Faktor Eksternal & Peluang & Ancaman \\
\hline 1. & $\begin{array}{l}\text { Produk Jasa (The } \\
\text { Service Product) }\end{array}$ & $\begin{array}{l}\text { - Terbukanya peluang untuk } \\
\text { menambah mata pelajaran } \\
\text { dan program-program } \\
\text { baru. }\end{array}$ & $\begin{array}{l}\text { - Adanya kompetitor yang } \\
\text { menawarkan produk dengan } \\
\text { jumlah mata pelajaran yang } \\
\text { lebih banyak. }\end{array}$ \\
\hline 2. & Harga (Price) & $\begin{array}{l}\text { - Kemampuan menguasi } \\
\text { pasar dan menciptakan } \\
\text { persaingan dengan } \\
\text { mempertahankan sistem } \\
\text { pembayaran SPP bulanan. }\end{array}$ & $\bullet$ \\
\hline 3. & $\begin{array}{l}\text { Tempat/Lokasi } \\
\text { Pelayanan } \\
\text { (Place/Service } \\
\text { Location) }\end{array}$ & $\begin{array}{l}\text { - } \text { Terbukanya peluang } \\
\text { membuka kantor unit } \\
\text { pembantu, }\end{array}$ & $\begin{array}{l}\text { - Adanya kompetitor yang } \\
\text { memiliki lokasi pelayanan } \\
\text { dua hingga tiga tempat. }\end{array}$ \\
\hline 4. & $\begin{array}{l}\text { Promosi } \\
\text { (Promotion) }\end{array}$ & $\begin{array}{l}\text { - Terbukanya peluang untuk } \\
\text { menjalin kerjasama dengan } \\
\text { pihak sekolah dalam hal } \\
\text { bimbingan olimpiade, try } \\
\text { out serentak, serta event- } \\
\text { event besar lainnya, } \\
\text { - Peluang melakukan } \\
\text { promosi skala nasional } \\
\text { melalui media elektrinik } \\
\text { maupun internet. }\end{array}$ & $\begin{array}{l}\text { - Tren promosi melalui media } \\
\text { internet, televisi, dan } \\
\text { billboard. }\end{array}$ \\
\hline 5. & $\begin{array}{l}\text { Orang/partisipan } \\
\text { (People) }\end{array}$ & $\begin{array}{l}\text { - Terbukanya peluang untuk } \\
\text { melakukan recruitment } \\
\text { tenaga pengajar freelance } \\
\text { untuk program bimbingan }\end{array}$ & $\begin{array}{l}\text { - Adanya les private yang } \\
\text { dilakukan } \\
\text { perorangan } \\
\text { tenaga } \\
\text { dengan }\end{array}$ \\
\hline
\end{tabular}




\begin{tabular}{|c|c|c|c|}
\hline & & $\begin{array}{l}\text { ke rumah-rumah/ sekolah } \\
\text { sesuai keinginan } \\
\text { konsumen, }\end{array}$ & $\begin{array}{l}\text { melayani untuk datang } \\
\text { kerumah konsumen. }\end{array}$ \\
\hline 6. & $\begin{array}{l}\text { Fasilitas Penunjang } \\
\text { (Physical Evidence) }\end{array}$ & $\begin{array}{l}\text { - Fasilitas kantin sehat dapat } \\
\text { dimanfaatkan sebagai } \\
\text { sarana promosi, } \\
\text { - Halaman yang luas adalah } \\
\text { sebuah peluang untuk } \\
\text { melaksanakan event untuk } \\
\text { menarik perhatian calon } \\
\text { kunsumen, } \\
\text { - Terbukanya peluang } \\
\text { mengadakan ruang baca/ } \\
\text { mini perpustakaan. }\end{array}$ & $\begin{array}{l}\text { - Adanya kompetitor yang } \\
\text { memiliki fasilitas sama } \\
\text { dengan fungsi fasilitas yang } \\
\text { berjalan dengan baik. }\end{array}$ \\
\hline 7. & Proses (Process) & $\begin{array}{l}\text { - } \text { Terbukanya peluang } \\
\text { membuka layanan } \\
\text { operasional pada waktu } \\
\text { pagi hari, } \\
\text { - Terbukanya peluang } \\
\text { membuka stand layanan } \\
\text { yang tidak hanya terfokus } \\
\text { pada tempat/lokasi } \\
\text { playanan saja. }\end{array}$ & $\begin{array}{l}\text { - Adanya kompetitor yang } \\
\text { menawarkan waktu } \\
\text { pelayanan mulai dari pagi } \\
\text { hari, }\end{array}$ \\
\hline
\end{tabular}

\section{Pembahasan Hasil Penelitian}

Bauran pemasaran (marketing mix) belum seimbang, bauran pemasaran (marketing mix) tidak statis, bauran pemasaran (marketing mix) tidak meniru, bauran pemasaran (marketing mix) bertujuan jangka panjang, bauran pemasaran (marketing mix) disesuasikan dengan situasi dan kondisi perusahaan,

\section{KESIMPULAN}

Berdasarkan hasil penelitian dan pembahasan pada bab sebelumnya, bahwa lembaga pendidikan prima mandiri utama dirintis dari les private yang dilakukan dari rumah ke rumah sejak tahun 2006 kemudian perlahan mendirikan lembaga pendidikan yang memiliki legalitas mulai dari Gama Mandiri, kemudian Prima Mandiri, hingga akhirnya pada tahun 2015 lembaga pendidikan Prima Mandiri Utama mempatenkan dirinya dan kokoh berdiri hingga saat ini. Analisis SWOT terhadap pelaksanaan bauran pemasaran (marketing mix) pada lembaga pendidikan prima mandiri utama Palangka Raya, dalam pembahasannya dapat ditarik kesimpulan sebagai berikut:

1. Pelaksanaan bauran pemasaran (marketing mix) yang meliputi tujuh variabel yaitu produk jasa, harga, promosi, tempat/lokasi pelayanan, fasilitas penunjang, dan proses dijalankan belum sepenuhnya seimbang, adanya skala prioritas pada variabel-variabel tertentu seperti harga, tempat/ lokasi pelayanan, promosi, dan orang/ partisipan saja, sementara untuk variabel produk jasa, fasilitas penunjang, dan variabel proses pelaksanaannya masih memiliki kekurangan dan ancaman yang berarti, dalam tumbuh kembang lembaga pendidikan prima mandiri utama.

2. Pelaksanaan bauran pemasaran (marketing mix) yang dijalankan oleh lembaga pendidikan prima mandiri utama selalu berinovasi dan menyesuaikan dengan perkembangan zaman, dalam arti kata bahwa pelaksanaan bauran pemasaran (marketing mix) pada lembaga pendidikan prima mandiri utama tidak statis atau jalan ditempat saja, melainkan menyeseuaikan diri dan cepat beradaptasi dengan perubahan dan perkembangan kurikulum serta pola pendidikan yang berjalan.

3. Pelaksanaan bauran pemasaran (marketing mix) yang dijalankan memiliki strategi tersendiri yang dilakukan tanpa meniru strategi dari bimbingan belajar (bimbel) pesaing. Lembaga pendidikan 
prima mandiri utama berani membuat trobosan baru yang belum pernah dilakukan oleh bimbingan belajar (bimbel) pesaing dalam hal strategi, baik promosi maupun mekanisme pembelajaran.

4. Pelaksanaan bauran pemasaran (marketing mix) belum memiliki program jangka panjang, hal ini dikarenakan manajeman lembaga pendidikan prima mandiri utama sedang fokus pada pengembangan cabang ke kota-kota lain selain Palangka Raya.

5. Pelaksanaan bauran pemasaran (marketing mix) disesuaikan dengan situasi dan kondisi perusahaan, penargetan jumlah siswa dilakukan beriringan dengan perhitungan keuangan serta pengukuran kapasitas fasilitas (ruang kelas dan tenaga pengajar) yang dimiliki oleh lembaga pendidikan prima mandiri utama.

Selanjutya secara umum dapat disimpulkan bahwa kekuatan lembaga pendidikan prima mandiri utama terletak pada biaya SPP (sumbangan pembinaan pendidikan) yang pembayarannya dilakukan secara bulanan tidak semesteran, seingga akan terasa lebih meringankan orang tua/ wali siswa. Selain itu tempat/ lokasi pelayanan yang strategis, promosi yang dilakukan dengan turun langsung ke lapangan bertemu konsumen, dan tenaga pengajar yang minimal berpendidikan sarjana hingga ada yang lulusan program magister merupakan unsur-unsur yang diunggulkan oleh lembaga pendidikan prima mandiri utama. Kelemahan lembaga pendidikan prima mandiri utama terletak pada produk yang dimiliki hanya tiga mata pelajaran, sementara kebutuhan konsumen tidak hanya itu. Selain produk, fasilitas penunjang yang dimiliki sebagian belum dilakukan perawatan yang baik sehingga mengganggu fungsi dari fasilitas tersebut, dan kelemahan seanjutnya adalah proses pelayanan administrasi pada waktu pagi hari masih belum terskruktur dengan baik.

Meski demikian lembaga pendidikan prima mandiri utama memiliki peluang untuk menambah produk diluar tiga produk yang sudah dimiliki, membuka kantor pelayanan baru yang akan menjangkau lebih luas konsumen, meningkatkan jangkauan promosi melalui media-media, merekrut lebih banyak tenaga pengajar freelance, memperbaiki dan menambah fasilitas penunjang, serta memiliki peluang mendapat lebih banyak siswa dengan membuka pelayanan administrasi di pagi hari. Sementara itu ancaman yang membayangi lembaga pendidikan prima mandiri utama berasal dari kompetitor/ bimbingan belajar (bimbel) pesaing yang memiliki keunggulan produk, tempat, serta proses yang lebih dari lembaga pendidikan prima mandiri utama, serta ancaman terhadap rawan terjadinya konflik internal antar individu maupun antar divisi pada lembaga pendidikan prima mandiri utama tersebut.

\section{DAFTAR PUSTAKA}

Assauri, Sofjan. 2002. Manajemen Pemasaran, Konsep Dasar Strategi. Jakarta: PT. Raja Grafindo Persada.

Arikunto, Suharsimi. 2006. Prosedur Penelitian Suatupendekatanpraktik. Jakarta: Rineka Cipta.

Andrasmoro, Dony. 2013. Pengembangan Potensi Pariwisata Pendidikan Geografi Dengan Analisis Kurikulum Pembelajaran Geografi Dan Analisis SWOT Dalam Upaya Meningkatkan Daya Tarik Wisata Di Kabupaten Karangnyar Tahun 2013. Surakarta: UNS

Buchari, Alma. 2007. Manajemen Pemasaran edisi revisi. Jakarta: LP-FEUI.

Cahandra, Gregorius. 2001. Service Quality and Satisfacation. Yogyakarta: Andi

Candra, Arifa. 2009. Analisis Bauran Pemasaran (marketing mix) jasa pada PT.FBC Indonesia. Surakarta: UNS

David. 2006. Manajemen Strategik. Jakarta: Salemba Empat.

Daryanto. 2011. Sari Kulia Manajemen Pemasaran. Bandung: PT. Sarana Tutorial Nurani Sejahtera.

Endah, Ari. 2004. Pelaksanaan Marketing Mix Meubel. UPR: Grennery.

Frinces, Heflin. 2006. Manajemen Strategik. Jogjakarta: Media Pustaka.

Goh, T.H Sunny, dan Khoo Kheng-Hor. 2005. Marketing Wise. Jakarta: PT. Bhuana Ilmu Populer.

Hamalik, Oemar. 2004. Proses Belajar Mengajar. Jakarta: Bumi Aksara.

Hurriyati, Ratih. 2005. Pemasaran dan Loyalitas Konsumen. CV. Alfa Beta: Bandung. 
Kotler, Philip. 2000. Marketing Manajemen. Jakarta : Prenhalindo.

Kotler, Philip. 2006. Manajemen Pemasaran, Analisis Perencanaan, Implementasi dan Kontrol. Jakarta: Prenhalindo.

Kotler, Philip. 2009. Manajemen Pemasaran edisi 13. Jakarta: Erlangga.

Lamb, Hair. 2001. Pemasaran Buku 2. Jakarta :Bumi Aksara

Lion, Eddy, dan Helmuth Y.B. 2013. Metodologi Penelitian Kualitatif. Surabaya: Jenggala Pustaka Utama. Masrudi, Saring. 2003. Layanan Bimbingan Konseling di Sekolah. Surakarta: UMS

Moleong, Lexy J. 2007. Metodologi Penelitian Kualitatif. Bandung : PT. Remaja Rordakarya.

Mulyadi. 2007. Sistem Perencanaan dan Pengendalian Manajemen. Jakarta: Salemba Empat

Mulyadi. 2010. Diagnosis Kesulitan Belajar dan Bimbingan Terhadap Kesulitan Belajar Khusus. Yogyakarta: Nuha Litera

Nitisemito, Alex S. 2000. Marketing Edisi Revisi I. Jakarta: Liberti.

Priyatno. 2004. Dasar-dasar Bimbingan dan Konseling. Jakarta : PT. Rineka Cipta

Purwati, Anik. 2012. Alternatif Pemilihan Strategi Pemasaran Berdasarkan Analisa SWOT Pada CV. Bimo Krisno Tour and Travel Jember. Jember : Universitas Jember.

Rodiosunu. 2001. Kerangka Dasar Manajemen Pemasaran. Bandung: Tristo

Rangkuti, Freddy. 2004. Analisis SWOT Teknik Membedah Kasus Bisnis. Jakarta: Gramedia Pustaka Utama.

Rangkuti, Freddy. 2006. Analisis SWOT Teknik Membedah Kasus Bisnis. Jakarta : Gramedia Pustaka Utama.

Rima MEILINDA. 2020. Analisis SWOT Marketing MIX Pada SMA Muhammadiyah 1 Palangka Raya. Edunomics Journal. Vol. 1 No. 1 Hal. 8-13, Juli 2020.

Swastha, Basu. 2002. Manajemen Pemasaran. Edisi Kedua. Cetakan Kedelapan. Jakarta: Liberty.

Setiowati, Berti. 2007. Analisis Strategi Bauran Pemasaran Pada Perusahaan Jasa Freight Forwarding: Rencana, Implementasi, dan Evaluasi Kebijakan Yang Mempengaruhi Kinerja Pemasaran Semarang: Universitas Diponegoro.

Sugiyono. 2007. Metode Penelitian Kuantitatif, Kualitatif, dan R\&D. Bandung: Alfabeta.

Sugiyono. 2009.Metode Penelitian Bisnis (Pendekatan Kuantitatif, Kualitatif, dan R \&D), Bandung : CV. Alfabeta.

Stevani, Fruri. 2015. Pengelolaan Bauran Pemasaran Jasa Penyelenggara Pesta Pernikahan (Feast Wedding Organizer) Pada CV. Prakaryabojonegoro Implementasi Pada Pelatihan Karyawan. Surakarta: UNS

Sundari Sundari, Revnussa Oktobery, Jacob Abolladaka. 2020. Strategi Usaha Dengan Analisis SWOT Pada Rental Adinda Palangka Raya. Jurnal Pendidikan Ilmu Pengetahuan Sosial (JPIPS). Vol. 12 No. 1. Hal. 49-56. Juni 2020.

Tjiptono, Fandy. 2008. Manajemen Pemasaran. Yogyakarta : CV. ANDI OFFSET.

Walgito, Bimo. 2004. Bimbingan dan Konseling di Sekolah. Yogyakarta: Andi

Winarti, Sih. 2015. Panduan Penulisan Usulan Penelitian dan Thesis. Palangka : UPR

Zethaml A.V, dan Marry jo Bitner. 2000. Service Marketing. Mc graw hill, new jersey. 